\title{
Czynnik różnicowania wzrostu 15 jako biomarker w niewydolności serca
}

\section{Growth differentiation factor 15 as a biomarker in heart failure}

\author{
Wiesław Piechota ${ }^{1}$, Paweł Krzesiński ${ }^{2}$ \\ ${ }^{1}$ Zakład Diagnostyki Laboratoryjnej Wojskowego Instytutu Medycznego w Warszawie \\ ${ }^{2}$ Klinika Kardiologii i Chorób Wewnętrznych Wojskowego Instytutu Medycznego w Warszawie
}

\section{Streszczenie}

Niewydolność serca (HF) staje się coraz częstszym rozpoznaniem ze spektrum chorób układu sercowo-naczyniowego. Częściowo jest to związane z wydłużeniem się średniego życia człowieka. Poprawiła się również diagnostyka HF, zarówno obrazowa, jak i biochemiczna - ta ostatnia dzięki wprowadzeniu rutynowych oznaczeń peptydów natriuretycznych typu B (BNP). Ze względu na poważne rokowanie (krótki czas przeżycia) nadal jednak trwają poszukiwania biomarkerów, które mogłyby mieć zastosowanie w jak najwcześniejszej diagnostyce, określeniu ciężkości HF, sposobu i efektywności (monitorowania) jej leczenia i, co nie mniej ważne, w rokowaniu. Jeden spośród kilku badanych nowych markerów - czynnik różnicowania wzrostu 15 (GDF-15) - zdaje się wykazywać względnie duży potencjał w powyższych zastosowaniach. Na czoło wybija się prognostyczna wartość tego białkowego biomarkera w odniesieniu do umieralności, niezależna od innych biomarkerów i dodatkowa w stosunku do nich. Wynika to ze złożonych procesów patofizjologicznych prowadzących do wzrostu stężenia tego markera, gdyż ekspresja GDF-15 nasila się w komórkach układu sercowo-naczyniowego (kardiomiocytach, śródbłonku) oraz innych komórkach (makrofagach, adipocytach) w odpowiedzi na bodźce patologiczne (niedokrwienie, stres oksydacyjny, zapalenie). Zwiększona ekspresja może mieć autokrynne działanie ochronne. Badania populacyjne wskazują także na możliwość zastosowania GDF-15 do wykrywania subklinicznej HF. Wartość kliniczna oznaczania GDF-15 zwiększa się w strategii wielomarkerowej, uwzględniającej zastosowanie wraz z BNP i/lub troponinami. Czynnik różnicowania wzrostu 15 może zatem odgrywać istotną rolę w biochemicznym systemie wczesnego ostrzegania o możliwości rozwoju HF oraz rokowaniu w przypadku jej wystąpienia.

Słowa kluczowe: czynnik różnicowania wzrostu 15, niewydolność serca, biomarker

Folia Cardiologica 2018; 13, 2: 174-180

\section{Wstęp}

Znaczenie biomarkerów w kardiologii jest coraz większe w związku z ich przydatnością w diagnostyce, monitorowaniu leczenia i ocenie rokowania wielu chorób układu sercowo-naczyniowego. Wydaje się to szczególnie przydatne w postępowaniu u chorych z niewydolnością serca (HF, heart failure). Jednym z takich białek jest czynnik różnicowania wzrostu 15 (GDF-15, growth differentiation factor 15). Jego znaczenie prognostyczne w chorobach układu sercowo-naczyniowego potwierdzono w wielu badaniach [1-5]. Wynika z nich, że stężenie GDF-15 jest silnie związane z ryzykiem wystąpienia twardych punktów końcowych, takich jak zgon, wystapienie HF, zawał serca.

Podwyższenie zlogarytmowanego stężenia GDF-15 o jedno odchylenie standardowe w populacji mężczyzn w podeszłym wieku wiązało się ze wzrostem ryzyka zgonu sercowo-naczyniowego o 48\% (95-proc. przedział ufności

Adres do korespondencji: dr hab. n. med. Paweł Krzesiński, Klinika Kardiologii i Chorób Wewnętrznych, Wojskowy Instytut Medyczny, ul. Szaserów 128, 04-141 Warszawa, e-mail: pkrzesinski@wim.mil.pl 
[confidence interval] 26-73\%; $p<0,001)$, niezależnie od innych czynników ryzyka (obserwacja 10-letnia) [1]. W populacji Framingham Heart Study jednoczesne podwyższenie wartości trzech markerów (GDF-15, peptydu natriuretycznego typu B [BNP, B-type natriuretic peptide] i troponiny I oznaczonej metoda wysokoczułą [hsTnl, high-sensitive troponin I]) do poziomu ich najwyższych kwartyli 6-krotnie zwiększało ryzyko wystąpienia HF, a ryzyko zgonu - około 3-krotnie (obserwacja 11-letnia) [2]. Liczba publikacji dotyczących GDF-15 u pacjentów z HF się zwiększa, czego wyrazem jest pierwsza metaanaliza 21 oryginalnych badań z udziałem 20920 chorych [6]. Potwierdza ona jednoznacznie fakt, że GDF-15 jest silnym predykatorem śmiertelności ogólnej u pacjentów z HF.

U pacjentów z zawałem serca bez uniesienia odcinka ST (NSTEMI, non-ST-elevation myocardial infarction) wyjściowe stężenia GDF-15 wiązały się wyraźnie z ryzykiem zgonu w ciągu trwającej rok obserwacji - częstość zgonów wzrastała w kolejnych tercylach jego stężenia i wynosiła, odpowiednio, 1,5\%, 5,0\% i 14,1\% ( $<<0,001)$ [3]. Dodanie GDF-15 do skali ryzyka GRACE (Global Registry Of Acute Cardiac Events) poprawiało stratyfikację ryzyka (wystąpienia) zgonu i ponownego zawału niezakończonego zgonem [4]. W innej pracy GDF-15 okazał się także istotnym czynnikiem predykcyjnym zgonu i pozawałowej HF u chorych z przebytym zawałem serca [7]. Istotna klinicznie jest również ostatnio uznana rola GDF-15 jako predyktora dużych krwawień u pacjentów z migotaniem przedsionków leczonych przeciwzakrzepowo [8].

Dowodów naukowych na ten temat sukcesywnie przybywa, choć nadal jest wiele niewiadomych dotyczących mechanizmów biochemicznych i molekularnych działania GDF-15, jego roli w diagnostyce różnicowej chorób serca i potencjalnego zastosowania w monitorowaniu terapii HF. W ostatnim czasie pojawiły się możliwości metodyczne łatwego, dokładnego i szybkiego oznaczenia GDF-15 w warunkach standardowego laboratorium medycznego. Dlatego wydaje się ważne przedstawienie szerszego podsumowania potencjalnych zastosowań tego nowego markera w ocenie chorych z HF, co stanowi temat niniejszej pracy.

\section{Znaczenie biologiczne GDF-15}

Czynnik różnicowania wzrostu 15 jest peptydem należącym do rodziny transformującego czynnika wzrostu $\beta$ (TGF- $\beta$, transforming growth factor $\beta$ ) [9]. W warunkach fizjologicznych ekspresja GDF-15 występuje w łożysku, prostacie, nerkach i w jelicie grubym [10]. Wyraźne nasilenie ekspresji GDF-15 z udziałem czynnika transkrypcyjnego p53 obserwuje się w makrofagach, kardiomiocytach i komórkach śródbłonka - najczęściej wskutek ich uszkodzenia, niedokrwienia lub stymulacji przez prozapalne cytokiny i reaktywne rodniki tlenowe [11-13] (ryc. 1) [14, 15]. Zwiększone stężenia GDF-15 pojawiają się we krwi w wielu stanach patologicznych, takich jak między innymi HF, miażdżyca, migotanie przedsionków, zatorowość płucna, ostre stany zapalne, przewlekła choroba nerek, a nawet nowotwory. Czynnik różnicowania wzrostu 15 okazał się przede wszystkim silnym predyktorem powikłań i umieralności w przebiegu tych schorzeń $[1,16]$. Od niedawna powszechnie dostępna immunochemiczna metoda chemiluminescencyjna

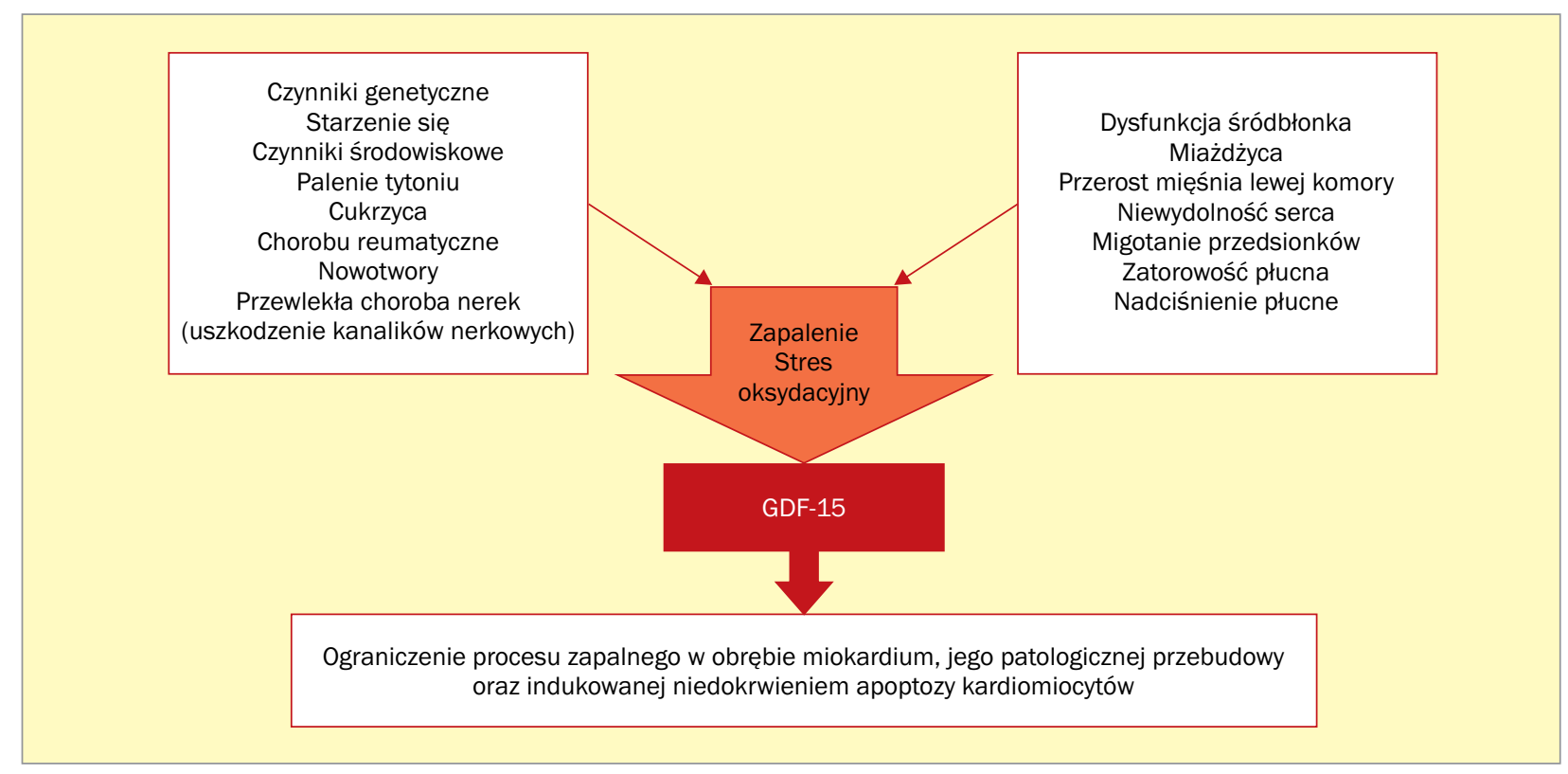

Rycina 1. Czynniki wpływające na stężenie czynnika różnicowania wzrostu 15 (GDF-15, growth differentiation factor 15) i potencjalny wpływ tego biomarkera na mięsień sercowy (na podstawie $[14,15]$ ) 
umożliwiła zautomatyzowanie oznaczania GDF-15, a tym samym jego szersze wykorzystanie [17]. Przeważająca liczba dotychczasowych badań wskazuje na trzy przedziały ryzyka sercowo-naczyniowego: stężenia poniżej 1200 ng/l odpowiadają niskiemu ryzyku (górna granica wartości referencyjnych dla osób zdrowych), 1200-1800 ng/l umiarkowanemu (przeciętnemu) ryzyku, a przekraczające 1800 ng/l - wysokiemu ryzyku [18].

\section{Czynnik różnicowania wzrostu 15 jako marker zaawansowania HF}

Według najnowszych wytycznych Europejskiego Towarzystwa Kardiologicznego (ESC, European Society of Cardiology) [19], na podstawie stopnia uszkodzenia lewej komory, wyróżnia się obecnie 3 grupy HF: $z$ istotnie obniżoną frakcją wyrzutową lewej komory (LVEF, left ventricular ejection fraction) - poniżej 40\% (HFrEF, heart failure with reduced ejection fraction), z łagodnie upośledzoną LVEF - 40-49\% (HFmrEF, heart failure with mild reduced ejection fraction) oraz z zachowaną frakcją wyrzutową (EF, ejectiona fraction), czyli wynosząca ponad 50\% (HFpEF, heart failure with preserved ejection fraction).

Wzrost stężenia krążącego GDF-15 u pacjentów z przewlekłą HF wykazali po raz pierwszy Kempf i wsp. [20]. Mediana wartości referencyjnych w całej grupie $(n=497$, rozstęp międzykwartylowy 59-71 lat) wynosiła 762 ng/l, a rozstęp międzykwartylowy -600-959 ng/l. Za górną granicę wartości referencyjnych przyjęto 1200 ng/l. W grupie pacjentów z przewlekłą HF mediana stężenia GDF-15 była ponad 2-krotnie wyższa od tego granicznego poziomu i wynosiła 2705 ng/l. Stężenie GDF-15 było ściśle związane z zaawansowaniem HF wyrażonym jako klasa niewydolności według New York Heart Association (NYHA).

W następnej pracy dotyczącej znaczenia GDF-15 w przewlekłej HF pracy Kempf i wsp. [5] potwierdzili prognostyczną użyteczność tego markera. Badaniem objęto 455 pacjentów z przewlekłą HF z medianą LVEF wynoszącą 32\% (przedział międzykwartylowy 25-39\%). Mediana GDF-15 oznaczonego metodą immunoradiometryczną wyniosła $1949 \mathrm{ng} / \mathrm{I}$ (przedział międzykwartylowy 1194-3577 ng/I). U większości pacjentów (74,9\%) wartości tego markera wynosiły powyżej 1200 ng/l - górnej granicy wartości prawidłowych dla osób w podeszłym wieku. Stężenia GDF-15 wiązały się z klasą według NYHA i stężeniem N-końcowego propeptydu natriuretycznego typu B (NT-proBNP, N-terminal pro B-type natriuretic peptide). W czasie 48 miesięcy obserwacji częstość zgonów wzrastała wyraźnie wśród pacjentów z najwyższymi stężeniami GDF-15 i w kolejnych kwartylach wynosiła, odpowiednio, 10,0\%, 9,4\%,33,4\% i 56,2\%; p < 0,001. Do stratyfikacji ryzyka w badanej populacji autorzy przyjęli punkt odcięcia GDF-15 równy zaokrąglonej medianie (> 2000 ng/l) lub wartości 2729 ng/l (punkt odcięcia na podstawie krzywej
ROC [receiver operating characteristic]). Podwyższone stężenie GDF-15 okazało się mieć istotną wartość predykcyjną w przewidywaniu ryzyka zgonu z jakiejkolwiek przyczyny, niezależną między innymi od wieku, płci, klasy według NYHA, odsetka LVEF i stężenia NT-proBNP (współczynnik ryzyka $[\mathrm{HR}$, hazard ratio] dla InGDF-15 = 2,26; $95 \% \mathrm{Cl}$ 1,52-3,37; $p<0,001)$.

Stężenie GDF-15 okazało się porównywalne w HF z zachowaną LVEF ( $\geq 50 \%)$ i zmniejszoną LVEF (< 50\%) [21]. Odróżnia to ten marker od NT-proBNP i troponin, których stężenia na ogół są wyższe u pacjentów ze zmniejszoną LVEF [22]. Zatem oznaczanie wyłącznie GDF-15 nie różnicowało tych dwóch postaci HF. Stało się to możliwe po dodatkowym uwzględnieniu innych biomarkerów, w tym rozpuszczalnej izoformy receptora ST2 (sST2, soluble ST2). Dopiero określenie stosunku stężeń (białko C-reaktywne [CRP, C-reactive protein] + + GDF-15 + sST2)/NT-proBNP pozwoliło na efektywne różnicowanie typu HF (iloraz szans [OR, odds ratio] 3,7; 95\% Cl 1,9-8,5; $p<0,001$ ) [18]. Stężenie GDF-15 okazało się również skorelowane z echokardiograficznymi markerami dysfunkcji rozkurczowej oraz zmniejszeniem pojemności wyrzutowej serca [23].

Wzrost stężenia GDF-15 okazał się mieć również znaczenie w rzadszych postaciach kardiomiopatii. W grupie pacjentów ( $n=102)$ z kardiomiopatią przerostową stężenie GDF-15 wykazywało wyraźny związek z ciężkością choroby (I klasa wg NYHA [n= 45] v. III klasa wg NYHA [n=15]: 2878 v. 4159 pg/ml), co daje podstawy twierdzeniu, że marker ten mógłby służyć do monitorowania stanu czynnościowego pacjentów z tą chorobą [24]. W znacznie mniejszej grupie chorych $(n=30)$ z kardiomiopatią rozstrzeniową i schyłkową HF (IV klasa wg NYHA), o etiologii innej niż niedokrwienna, stężenie GDF-15 w krążeniu obniżało się wyraźnie po 1 miesiącu od wszczepienia urządzenia wspomagającego lewą komorę serca i pozostawało stabilnie obniżone w czasie dalszej, trwającej 6 miesięcy, obserwacji [25]. Stężenia GDF-15 były skorelowane z czynnością nerek i nasileniem włóknienia mięśnia sercowego. Podkreśla się jednak, że źródłem GDF-15 w tych chorobach może być nie tylko mięsień sercowy (tak jak w zawale serca), ale także inne tkanki.

W ostrej HF wśród 1161 pacjentów objętych badaniem RELAX-AHF wyjściowe stężenie GDF-15 nie było związane z częstością występowania złożonego punktu końcowego (ponowna hospitalizacja z powodu HF lub nerek i zgonu sercowo-naczyniowego w ciągu $60 \mathrm{dni}$ ) ani zgonu sercowo-naczyniowego w ciągu 180 dni. Wykazano natomiast związek tych zdarzeń klinicznych ze zmianami stężenia GDF-15 w 2. i 14. dniu od wyjściowego oznaczenia [26]. W innym badaniu, znacznie mniejszym, bo obejmującym 90 pacjentów z ostrą HF lub wstrząsem kardiogennym, GDF-15 był silnym predykatorem umieralności w ciągu 30 dni. Ryzyko zgonu było 5,1 razy wyższe u pacjentów ze 
stężeniami GDF-15 w 3. tercylu w porównaniu z pacjentami ze stężeniami tego markera w 1. tercylu [27].

\section{Czynnik różnicowania wzrostu 15 w monitorowaniu HF}

Rola GDF-15 jako markera monitorowania efektów leczenia HF pozostaje niezbadana. Nie jest też jasne, czy w toku skutecznego leczenia jego stężenia zachowywałyby się podobnie do wartości BNP [28]. U pacjentów z HF leczonych walsartanem stężenie GDF-15 po 12 miesiącach leczenia było wyższe niż wyjściowe, natomiast stężenie BNP obniżyło się [29]. Przydatność GDF-15 do monitorowania leczenia byłaby szczególnie pożądana w przypadku leków hamujących działanie neprylizyny endopeptydazy rozkładającej peptydy natriuretyczne, takie jak sakubitril/walsartan (LCZ696) o jednoczesnym działaniu antagonisty receptora angiotensyny (ARNI, angiotensin receptor neprilisin inhibitor) [30]. Obecnie u tych chorych wykorzystuje się oznaczenie NT-proBNP, gdyż nie jest on rozkładany przez neprylizynę. Stężenie NT-proBNP może być jednak także częściowo obniżone wskutek nasilenia przez neprylizynę glikozylowania tej cząsteczki, co skutkuje jej upośledzonym rozpoznawaniem przez przeciwciała testu [31, 32].

Niejednorodny jest również wpływ leków na GDF-15. Seralaksyna, rekombinowana postać ludzkiego hormonu relaksyny, obniża stężenie GDF-15 u pacjentów z ostrą HF [33] (badanie III fazy tego leku przerwano z powodu jego zbyt małej skuteczności) [34]. Nie stwierdzono wpływu leczenia statynami na wartość GDF-15 u pacjentów stabilnym stanie po ostrym zespole wieńcowym (nawet gdy leczenie było intensywne) [35]. Również u chorych na cukrzycę leczonych statynami nie odnotowano takiego efektu [36]. Wiadomo zaś, że niesteroidowe leki przeciwzapalne (NLPZ), które powodują zwiększenie ryzyka zawału serca [37] i nasilenie objawów przewlekłej HF [38], zwiększają ekspresję GDF-15 [39] (stąd inna nazwa GDF-15: NSAID-activated protein 1).

\section{Czynnik różnicowania wzrostu 15 w przewidywaniu HF}

Udowodniono również przydatność GDF-15 w przewidywaniu wystąpienia HF $[40,41]$. W dużym, wieloośrodkowym badaniu STABILITY (Stabilization of Atherosclerotic Plaque by Initiation of Darapladib Therapy Trial) [42], z udziałem 14577 pacjentów ze stabilną chorobą wieńcową i obciążonych przynajmniej jednym dodatkowym klinicznym czynnikiem ryzyka sercowo-naczyniowego, oznaczano stężenia GDF-15 oraz inne biochemiczne markery zdarzeń sercowo-naczyniowych, takie jak NT-proBNP, troponiny, cystatyne
C oraz CRP. Czynnik różnicowania wzrostu 15 okazał się silnym, niezależnym predyktorem zachorowalności i umieralności z powodu chorób układu sercowo-naczyniowego, w tym hospitalizacji z powodu HF (HR 5,8; 95\% Cl 3,2-10).

\section{Czynnik różnicowania wzrostu 15 w HF - uwagi praktyczne}

Dowiedziono, że na stężenie GDF-15 istotnie wpływa funkcja nerek. Okazało się podwyższone przy obniżonym przesączaniu kłębuszkowym (eGFR, estimated glomerular filtration rate), a wewnątrznerkowe nasilenie ekspresji GDF-15 mRNA u pacjentów z przewlekłą chorobą nerek było skorelowane ze stężeniem krążącego we krwi GDF-15 [43]. Każde podwojenie stężenia tego markera wiązało się z 72-procentowym wzrostem ryzyka progresji przewlekłej choroby nerek (zmniejszeniem eGFR o 30\%) w ciągu trwającej blisko 2 lata obserwacji. Na nasilenie wzrostu stężenia GDF-15 u chorych z HF wpływają także choroby współistniejące: cukrzyca, kacheksja, niedokrwistość. Stężenia GDF-15 są również związane z markerami zapalenia (CRP) i aktywacją neurohormonalną (norepinefryna w osoczu). Jednak powyższe czynniki ryzyka i biomarkery odpowiadają za mniej niż połowę zmienności międzyosobniczej wartości GDF-15 we krwi [5, 26].

Zwraca się również uwagę na istotną zmienność biologiczną GDF-15. W jednym z badań u pacjentów ze stabilną HF wyniosła ona $6,8 \%$ w ciągu 3 miesięcy pomiarów i nie zależała od wyjściowych stężeń tego markera [44]. Z innej pracy [45] odnotowano jednak większą zmienność biologiczną GDF-15 - równą 16,8\%, co należy uwzględniać w ocenie sekwencyjnej wartości tego biomarkera.

\section{Wnioski}

Czynnik różnicowania wzrostu 15 jest obecnie jednym z najsilniejszych biochemicznych markerów niekorzystnych zdarzeń sercowo-naczyniowych. Wyniki badań dotyczących jego zastosowania u chorych z HF wydają się obiecujące. Pojawienie się metod dokładnego, zautomatyzowanego oznaczania GDF-15 otwiera możliwość powszechnego stosowania go w tej populacji, jak również kontynuację badań naukowych w obszarach do tej pory budzących wątpliwości.

\section{Finansowanie}

Praca zrealizowana w ramach projektu statutowego MNiSW/ /WIM nr 213.

\section{Konflikt interesów}

Autorzy deklarują brak konfliktu interesów. 


\section{Abstract}

Prevalence of heart failure (HF) diagnosis has increased for the whole spectrum of cardiovascular diseases. The increase was partly due to extension of average life expectancy. In addition, HF diagnostic methods have also improved, including imaging and laboratory testing - especially routine B-type natriuretic peptides (BNP) determination. However, because of a serious prognosis (a short survival time) of the condition search for novel biomarkers that could be used in the initial diagnosis, determining the severity of HF, and effectiveness of treatment and, last but not least, in the prognosis is still underway. Among several investigational new markers one of them - growth differentiation factor 15 (GDF-15) seems to have a relatively high potential in the above applications. The most pronounced feature of this protein biomarker is its predictive value of HF and all-cause mortality, independent of other biomarkers and additive to them. This is due to variety of complex pathophysiological processes leading to the increase of the marker concentration. Growth differentiation factor 15 expression increases in cardiovascular cells (cardiomyocytes, endothelium) and other cells (macrophages, adipocytes) in response to pathological stimuli (ischaemia, oxidative stress, inflammation). The increased expression may have autocrine protective effect. Population-based studies also indicate the potential usefulness of the GDF-15 in detecting subclinical HF. Clinical value of GDF-15 increases by its use together with BNP and/or troponins (multimarker strategy). Growth differentiation factor 15 may therefore play an important role in the biochemical system of early warning about the probability of developing HF, and in assessing the risk of death when HF occurs.

Key words: growth differentiation factor 15 , heart failure, biomarker

Folia Cardiologica 2018; 13, 2: 174-180

\section{Piśmiennictwo}

1. Wallentin L, Zethelius B, Berglund L, et al. GDF-15 for prognostication of cardiovascular and cancer morbidity and mortality in men. PLoS One. 2013; 8(12): e78797, doi: 10.1371/journal.pone.0078797, indexed in Pubmed: 24312445.

2. Wang TJ, Wollert KC, Larson MG, et al. Prognostic utility of novel biomarkers of cardiovascular stress: the Framingham Heart Study. Circulation. 2012; 126(13): 1596-1604, doi: 10.1161/CIRCULATIONAHA.112.129437, indexed in Pubmed: 22907935.

3. Damman P, Kempf T, Windhausen F, et al. ICTUS investigators. Prognostic value of growth-differentiation factor-15 in patients with non-ST-elevation acute coronary syndrome. Circulation. 2007; 115(8): 962-971, doi: 10.1161/CIRCULATIONAHA.106.650846, indexed in Pubmed: 17283261.

4. Widera C, Pencina MJ, Bobadilla M, et al. Incremental prognostic value of biomarkers beyond the GRACE (Global Registry of Acute Coronary Events) score and high-sensitivity cardiac troponin $\mathrm{T}$ in non-ST-elevation acute coronary syndrome. Clin Chem. 2013; 59(10): 1497-1505, doi: 10.1373/clinchem.2013.206185, indexed in Pubmed: 23818444.

5. Kempf T, von Haehling S, Peter T, et al. Prognostic utility of growth differentiation factor-15 in patients with chronic heart failure. J Am Coll Cardiol. 2007; 50(11): 1054-1060, doi: 10.1016/j.jacc.2007.04.091, indexed in Pubmed: 17825714.

6. George M, Jena A, Srivatsan V. GDF 15 - a novel biomarker in the offing for heart failure. Curr Cardiol Rev. 2016; 12(1): 37-46, indexed in Pubmed: 26750722.

7. Khan SQ, Ng K, Dhillon 0 , et al. Growth differentiation factor-15 as a prognostic marker in patients with acute myocardial infarction. Eur Heart J. 2009; 30(9): 1057-1065, doi: 10.1093/eurheartj/ehn600, indexed in Pubmed: 19168526.

8. Hijazi Z, Oldgren J, Lindbäck J, et al. ARISTOTLE and RE-LY Investigators. A biomarker-based risk score to predict death in patients with atrial fibrillation: the $\mathrm{ABC}$ (age, biomarkers, clinical history) death risk score. Eur Heart J. 2018; 39(6): 477-485, doi: 10.1093/eurheartj/ /ehx584, indexed in Pubmed: 29069359.

9. Bootcov MR, Bauskin AR, Valenzuela SM, et al. MIC-1, a novel macrophage inhibitory cytokine, is a divergent member of the TGF-beta superfamily. Proc Natl Acad Sci U S A. 1997; 94(21): 11514-11519, indexed in Pubmed: 9326641.

10. Bauskin AR, Zhang HP, Fairlie WD, et al. The propeptide of macrophage inhibitory cytokine (MIC-1), a TGF-beta superfamily member, acts as a quality control determinant for correctly folded MIC-1. EMBO J. 2000; 19(10): 2212-2220, doi: 10.1093/emboj/19.10.2212, indexed in Pubmed: 10811612.

11. Hsiao EC, Koniaris LG, Zimmers-Koniaris T, et al. Characterization of growth-differentiation factor 15, a transforming growth factor beta superfamily member induced following liver injury. Mol Cell Biol. 2000; 20(10): 3742-3751, indexed in Pubmed: 10779363.

12. Kempf T, Eden M, Strelau J, et al. The transforming growth factor-beta superfamily member growth-differentiation factor-15 protects the heart from ischemia/reperfusion injury. Circ Res. 2006; 98(3): 351-360, doi: 10.1161/01.RES.0000202805.73038.48, indexed in Pubmed: 16397141.

13. Schlittenhardt D, Schober A, Strelau J, et al. Involvement of growth differentiation factor-15/macrophage inhibitory cytokine-1 (GDF-15/ /MIC-1) in oxLDL-induced apoptosis of human macrophages in vitro and in arteriosclerotic lesions. Cell Tissue Res. 2004; 318(2): 325-333, doi: 10.1007/s00441-004-0986-3, indexed in Pubmed: 15459768.

14. Wollert KC, Kempf T. Growth differentiation factor 15 in heart failure: an update. Curr Heart Fail Rep. 2012; 9(4): 337-345, doi: 10.1007/ /s11897-012-0113-9, indexed in Pubmed: 22961192.

15. Ago T, Sadoshima J. GDF15, a cardioprotective TGF-beta superfamily protein. Circ Res. 2006; 98(3): 294-297, doi: 10.1161/01. RES.0000207919.83894.9d, indexed in Pubmed: 16484622. 
16. Wollert KC, Kempf T, Wallentin L, et al. Growth differentiation factor-15: a new biomarker in cardiovascular disease. Herz. 2009; 34(8): 594-599, doi: 10.1007/s00059-009-3317-3, indexed in Pubmed: 20024638.

17. Wollert KC, Kempf T, Giannitsis E, et al. An automated assay for growth differentiation factor 15. JALM.; 2017, doi: 10.1373/jalm. 2016.022376.

18. Wollert KC, Kempf T, Lagerqvist Bo, et al. Growth differentiation factor 15 for risk stratification and selection of an invasive treatment strategy in non ST-elevation acute coronary syndrome. Circulation. 2007; 116(14): 1540-1548, doi: 10.1161/CIRCULATIONAHA.107.697714, indexed in Pubmed: 17848615.

19. Ponikowski P, Voors AA, Anker SD, et al. ESC Scientific Document Group. 2016 ESC Guidelines for the diagnosis and treatment of acute and chronic heart failure: The Task Force for the diagnosis and treatment of acute and chronic heart failure of the European Society of Cardiology (ESC)Developed with the special contribution of the Heart Failure Association (HFA) of the ESC. Eur Heart J. 2016; 37(27): 2129-2200, doi: 10.1093/eurheartj/ehw128, indexed in Pubmed: 27206819.

20. Kempf T, Horn-Wichmann R, Brabant G, et al. Circulating concentrations of growth-differentiation factor 15 in apparently healthy elderly individuals and patients with chronic heart failure as assessed by a new immunoradiometric sandwich assay. Clin Chem. 2007; 53(2): 284-291, doi: 10.1373/clinchem.2006.076828, indexed in Pubmed: 17185363.

21. Sinning C, Kempf T, Schwarzl M, et al. Biomarkers for characterization of heart failure - distinction of heart failure with preserved and reduced ejection fraction. Int J Cardiol. 2017; 227: 272-277, doi: 10.1016/j.ijcard.2016.11.110, indexed in Pubmed: 27838133.

22. Santhanakrishnan R, Chong JPC, Ng TP, et al. Growth differentiation factor $15, \mathrm{ST} 2$, high-sensitivity troponin $\mathrm{T}$, and $\mathrm{N}$-terminal pro brain natriuretic peptide in heart failure with preserved vs. reduced ejection fraction. Eur J Heart Fail. 2012; 14(12): 1338-1347, doi: 10.1093/ /eurjhf/hfs130, indexed in Pubmed: 22869458.

23. Dinh W, Füth R, Lankisch $M$, et al. Growth-differentiation factor-15: a novel biomarker in patients with diastolic dysfunction? Arq Bras Cardiol. 2011; 97(1): 65-75, indexed in Pubmed: 21584478.

24. Montoro-García S, Hernández-Romero D, Jover E, et al. Growth differentiation factor-15, a novel biomarker related with disease severity in patients with hypertrophic cardiomyopathy. Eur J Intern Med. 2012; 23(2): 169-174, doi: 10.1016/j.ejim.2011.08.022, indexed in Pubmed: 22284249.

25. Lok SI, Winkens B, Goldschmeding R, et al. Circulating growth differentiation factor- 15 correlates with myocardial fibrosis in patients with non-ischaemic dilated cardiomyopathy and decreases rapidly after left ventricular assist device support. Eur J Heart Fail. 2012; 14(11): 1249-1256, doi: 10.1093/eurjhf/hfs120, indexed in Pubmed: 22843564.

26. Cotter G, Voors AA, Prescott MF, et al. Growth differentiation factor 15 (GDF-15) in patients admitted for acute heart failure: results from the RELAX-AHF study. Eur J Heart Fail. 2015; 17(11): 1133-1143, doi: 10.1002/ejhf.331, indexed in Pubmed: 26333529.

27. Speidl WS, Krychtiuk K, Lenz M, et al. Growth differentiation factor-15 is associated with mortality in patients with severe acute heart failure or cardiogenic shock. J Am Coll Cardiol. 2017; 69(11): 749, doi: 10.1016/s0735-1097(17)34138-4.
28. Berezin AE. The growth/differentiation factor-15 in chronic heart failure: new challenge in biomarker-guided therapy? Transl Biomed. 2017; 8(1): 103, doi: 10.21767/2172-0479.1000103.

29. Anand IS, Kempf T, Rector TS, et al. Serial measurement of growth-differentiation factor-15 in heart failure: relation to disease severity and prognosis in the Valsartan Heart Failure Trial. Circulation. 2010; 122(14): 1387-1395, doi: 10.1161/CIRCULATIONAHA.109.928846, indexed in Pubmed: 20855664.

30. McMurray JJV, Packer M, Desai AS, et al. PARADIGM-HF Investigators and Committees. Angiotensin-neprilysin inhibition versus enalapril in heart failure. N Engl J Med. 2014; 371(11): 993-1004, doi: 10.1056/ /NEJMoa1409077, indexed in Pubmed: 25176015.

31. Jaffe AS, Apple FS, Mebazaa A, et al. Unraveling N-terminal pro-B-type natriuretic peptide: another piece to a very complex puzzle in heart failure patients. Clin Chem. 2015; 61(8): 1016-1018, doi: 10.1373/ /clinchem.2015.243626, indexed in Pubmed: 26078443.

32. Røsjø H, Dahl MB, Jørgensen M, et al. Influence of glycosylation on diagnostic and prognostic accuracy of N-terminal pro-B-type natriuretic peptide in acute dyspnea: data from the Akershus Cardiac Examination 2 Study. Clin Chem. 2015; 61(8): 1087-1097, doi: 10.1373/ /clinchem.2015.239673, indexed in Pubmed: 26056354.

33. Prescott MF, Zhang Y, Dahlke M, et al. Patent: use of serelaxin to reduce gdf-15. https://patents.google.com/patent/W02015189790A1/en (17.12.2015).

34. https://www escardio org/The-ESC/Press-Office/Press-releases/ /serelaxin-fails-to-meet-primary-endpoints-in-phase-3-relax-ahf-2-trial. Metra M, Teerlink JR. Serelaxin in acute heart failure. Heart Failure 2017 - 4th World Congress on Acute Heart Failure, 29 April 2017. (18.10.2017).

35. Bonaca MP, Morrow DA, Braunwald E, et al. Growth differentiation factor-15 and risk of recurrent events in patients stabilized after acute coronary syndrome: observations from PROVE IT-TIMI 22. Arterioscler Thromb Vasc Biol. 2011; 31(1): 203-210, doi: 10.1161/ /ATVBAHA.110.213512, indexed in Pubmed: 20966402.

36. Kim JiM, Back MK, Yi HS, et al. Effect of atorvastatin on growth differentiation factor-15 in patients with type 2 diabetes mellitus and dyslipidemia. Diabetes Metab J. 2016; 40(1): 70-78, doi: 10.4093/ /dmj.2016.40.1.70, indexed in Pubmed: 26616597.

37. Bally M, Dendukuri N, Rich B, et al. Risk of acute myocardial infarction with NSAIDs in real world use: bayesian meta-analysis of individual patient data. BMJ. 2017; 357: j1909, indexed in Pubmed: 28487435.

38. Arfè A, Scotti L, Varas-Lorenzo C, et al. Safety of Non-steroidal Anti-inflammatory Drugs (SOS) Project Consortium. Non-steroidal anti-inflammatory drugs and risk of heart failure in four European countries: nested case-control study. BMJ. 2016; 354: i4857, indexed in Pubmed: 27682515.

39. Wang X, Baek SJ, Eling TE. The diverse roles of nonsteroidal anti-inflammatory drug activated gene (NAG-1/GDF15) in cancer. Biochem Pharmacol. 2013; 85(5): 597-606, doi: 10.1016/j.bcp.2012.11.025, indexed in Pubmed: 23220538.

40. Kempf T, Sinning JM, Quint A, et al. Growth-differentiation factor-15 for risk stratification in patients with stable and unstable coronary heart disease: results from the AtheroGene study. Circ Cardiovasc Genet. 2009; 2(3): 286-292, doi: 10.1161/CIRCGENETICS.108.824870, indexed in Pubmed: 20031597.

41. Schopfer DW, Ku IA, Regan M, et al. Growth differentiation factor 15 and cardiovascular events in patients with stable ischemic heart 
disease (The Heart and Soul Study). Am Heart J. 2014; 167(2): 186-192.e1, doi: 10.1016/j.ahj.2013.09.013, indexed in Pubmed: 24439979.

42. Hagström E, Held C, Stewart RAH, et al. STABILITY Investigators. Growth differentiation factor 15 predicts all-cause morbidity and mortality in stable coronary heart disease. Clin Chem. 2017; 63(1): 325-333, doi: 10.1373/clinchem.2016.260570, indexed in Pubmed: 27811204.

43. Nair V, Robinson-Cohen C, Smith MR, et al. Growth differentiation factor-15 and risk of CKD progression. J Am Soc Nephrol. 2017;
28(7): 2233-2240, doi: 10.1681/ASN.2016080919, indexed in Pubmed: 28159780.

44. Frankenstein L, Remppis A, Frankenstein J, et al. Variability of N-terminal probrain natriuretic peptide in stable chronic heart failure and its relation to changes in clinical variables. Clin Chem. 2009; 55(5): 923-929, doi: 10.1373/clinchem.2008.112052, indexed in Pubmed: 19299545.

45. Meijers WC, van der Velde AR, Muller Kobold AC, et al. Variability of biomarkers in patients with chronic heart failure and healthy controls. Eur J Heart Fail. 2017; 19(3): 357-365, doi: 10.1002/ejhf.669, indexed in Pubmed: 27766733. 